\title{
Vergil's "White Bird" and the Alexandrian Reference (G. 2. 319-20)
}

\section{Citation}

Thomas, Richard F. 1988. Vergil's "White Bird" and the Alexandrian reference (G. 2. 319-20). Classical Philology 83(3): 214-217.

\section{Published Version}

doi:10.1086/367107

\section{Permanent link}

http://nrs.harvard.edu/urn-3:HUL.InstRepos:3775754

\section{Terms of Use}

This article was downloaded from Harvard University's DASH repository, and is made available under the terms and conditions applicable to Other Posted Material, as set forth at http:// nrs.harvard.edu/urn-3:HUL.InstRepos:dash.current.terms-of-use\#LAA

\section{Share Your Story}

The Harvard community has made this article openly available.

Please share how this access benefits you. Submit a story.

\section{Accessibility}


Our discussion has confirmed that there is no problem with the information about his age that Aeschines gives us in his speech against Timarchus; what we should not believe is his implication that Misgolas was older than Timarchus. As a result, we can accept Aeschines' statement that he was forty-five in 346/45 and infer that he was born in either $391 / 90$ or $390 / 89$. This conclusion also has implications for the career of Aeschines' fellow ephebe Nausicles, about whose date of birth we know nothing save that he was an exact contemporary of Aeschines: ${ }^{14}$ his birth also should be dated to $391 / 90$ or $390 / 89$. But these are not the only things to be gained from an examination of the problem. I hope that the discussion of the difficulties surrounding the evidence for Aeschines' date of birth has had some value in illustrating the kind of rhetorical legerdemain an orator might employ to deceive his audience. It is precisely this sort of deception that should make us wary when we are dealing with the information provided by the Attic orators. ${ }^{15}$

\section{EDWARD M. HARRIS \\ Brooklyn College and the Graduate Center, The City University of New York}

14. Aeschin. 2. 184; Davies, Athenian Propertied Families, p. 396, is thus incorrect to place his birth "in the region of $398-6$."

15. An earlier version of this note formed a part of chapter 2 of my dissertation, "The Political Career of Aeschines" (Harvard, 1983). I would like to thank Professor Badian, who directed my dissertation, for several helpful suggestions; thanks are also due to the Editor for his comments.

\section{VERGIL'S “WHITE BIRD” AND THE ALEXANDRIAN REFERENCE}

(G. 2. 319-20)

M. J. Harbinson has recently suggested a new identification for the white bird whose springtime appearance provides the farmer with a useful timetable for the planting of his vines (G. 2. 319-20):

$$
\begin{aligned}
& \text { optima vinetis satio, cum vere rubenti } \\
& \text { candida venit avis longis invisa colubris. }
\end{aligned}
$$

Harbinson proposes that this bird is the short-toed eagle (Circaetus gallicus), not the white stork (Ciconia ciconia) as most readers of Vergil believe. His arguments have the appearance of ornithological auctoritas, but none is convincing. ${ }^{1}$

\section{APPEARANCE}

Circaetus gallicus may have generally white underparts, although "its head and breast tend to be of a darker greyish brown"; the white stork, on the other hand, is "far from being entirely white. The primaries, secondaries, greater coverts and long scapulars are black." ${ }^{2}$ In other words, neither bird fully qualifies as candida

1. "Virgil's 'White Bird," $C Q 36$ (1986): 276-78. Because of limitations of space I shall summarize Harbinson's argument; I trust that I shall do justice to its thrust.

2. Ibid., p. 277. 
avis. But the fact is that nowhere ir. Latin is an eagle ever referred to as "white," whereas the general appearance and common name of the white stork (cigogne blanche, Weisstorch) speak for themselves. ${ }^{3}$ And the matter is virtually settled by Ovid Metamorphoses 6. 96-97, where the same adjective, candida, is applied to the stork:

... sumptis quin candida pennis

ipsa sibi plaudat crepitante ciconia rostro.

Whatever the ornithological realities, it looks as if Ovid may have taken Vergil's candida avis to be the stork.

\section{DISTRIBUTION}

Harbinson claims that the white stork "does not breed in Italy," that there is "[no] substantial evidence that it ever did in significant numbers," and that the candida avis is "therefore unlikely to be a migrating stork" that would arrive in the spring. ${ }^{4}$ But the modern evidence is somewhat forced here, ${ }^{5}$ while the ancient evidence is either ignored or misunderstood. Consider the following: Varro De re rustica (a text much used by Vergil in the Georgics) 3. 5.6 non ut advenae volucres pullos faciunt, in agro ciconiae, in tecto hirundines, sic aut hic aut illic turdi; Pliny Natural History 10.61 ciconiae quonam e loco veniant aut quo se referant incompertum adhuc est, 63 ciconiae nidos eosdem repetunt, 77 Larium lacum ... ad quem ciconiae non permeant, 78 in Fidenate agro iuxta urbem ciconiae nec pullos nec nidum faciunt; ${ }^{6}$ Petronius Satyricon 55 ciconia etiam, grata peregrina hospita ... avis exul hiemis; ${ }^{7}$ Claudianus Mamertus De statu animae p. 71, 13 Engelbrecht nidos ciconiae atque hirundines post annum revisunt; Sidonius Apollinaris Epistulae 2. 14. 2 usque ad adventum . . ciconinum; Isidore Origines 12.7 ciconiae veris nuntiae. ${ }^{8}$ In other words, the vernal return of the stork is in the Latin tradition the opposite of what Harbinson would have us believe: it is proverbial. That is one reason why Vergil does not need to name it explicitly; the words cum vere rubenti / candida venit avis are sufficient for the reader who is aware of the tradition.

Now it might be argued that none of the storks said to return in the spring is Ciconia ciconia. There is of course no way of knowing. The absence of a specific epithet, however, makes it clear that a number of authors, without concern for the actual species, considered the stork, regarded generically, to be a springtime migrant; and there exist "white" storks. This will have been enough for Vergil,

3. These common names partly distinguish the white stork from the black stork, but candidus is, after all, a relative term; cf. OLD, s.v. candidus 3: "white, of light colour (in contrast with darker varieties, parts, etc.)." So we speak of "white" wine, "white" sheep, the "white" race.

4. "Virgil's 'White Bird,"”p. 277.

5. The claim is based on S. C. Cramp, ed., The Birds of the Western Palearctic, vol. 1 (Oxford, 1977), which, however, merely states (p. 329) that the bird bred in the Po Valley until the fourteenth century but has not been appearing much in modern times.

6. These last two passages are adduced by Harbinson as evidence that the stork did not substantially breed in Italy - as if the statement "in Utah people do not drink beer" could be taken to imply anything but "in America people drink beer."

7. Cf. also Aug. Enarr. Ps. 58. I annuae nostrae hospites sunt ciconiae.

8. These last two references were provided by the journal's anonymous referee. 
the man who gave us that nonbird, the fulica marina ("sea-coot"), ${ }^{9}$ and who turned Aratus' raven (Phaen. 1003) into a crow (G. 1. 388).

\section{HABITAT}

Harbinson states that "the sighting of the white bird takes place in vineyards," and that storks, unlike short-toed eagles (which are fond of trees), prefer lowland pastures. ${ }^{10}$ But the sighting does not take place in the vineyard; Vergil merely says "the best time for planting vines is when the white bird arrives [in Italy]."

\section{FOOD}

The short-toed eagle feeds on snakes. On the other hand, Harbinson claims that Juvenal 14. 74-75 (serpente ciconia pullos / nutrit) does not refer to snakes and therefore cannot support the view that Vergil's phrase longis invisa colubris refers to the stork; rather, Harbinson says, Juvenal is referring to "creepy crawlies' in general." 11 The evidence? One Edward Topsell, who in 1608 averred: "By serpents we understand ... all venomous beasts whether creeping without legges, as adders and snakes, or with legges as crocodiles and lizards, or more nearly compacted bodies, as toades, spiders and bees; following heerin the warrant of the best ancient Latinists" (The History of Serpents). A glance at more conventional lexical tools (s.v. serpens) is all that is needed here; ${ }^{12}$ and those still skeptical need only return to Pliny, who reports $(H N 10.62)$ that in Thessaly the killing of a stork was a capital crime since the bird was prized for killing snakes. $^{13}$

No, we had better stay with the stork, whose literary appearance and attributes make it the best candidate. But the interest of Georgics 2. 319-20 is not yet exhausted. The manner of Vergil's reference is essentially Alexandrian; the name of the white bird is suppressed and is to be recovered from its attributes: the fact that it returns in the spring and is an enemy of the snake. In this poem such suppression, accompanied by an adjective or adjectival clause containing specific information about the subject in question, regularly points to a literary source. In the following examples, as in the case of our avis, a subject is mentioned only in a general way (cultor, arbor, pastor, anguis) and can be identified precisely only if the reader combines the accompanying details with his knowledge of the model:

(a) 1. 14-15 "cultor nemorum, cui pinguia Ceae / ter centum nivei tondent dumeta iuvenci." The identity of Aristaeus can be recovered only if one knows

9. G. 1. 362-63; cf. L. P. Wilkinson, The "Georgics" of Virgil (Cambridge, 1969), p. 235. Vergil is knowledgeable enough on many matters, but his knowledge comes chiefly from literary sources, and the Georgics is not primarily concerned with absolute, scientific truth. He cannot be held to the standards of the modern (or even ancient) scientific treatise, ornithological, horticultural, or astronomical.

10. “Virgil's 'White Bird,'” p. 278.

11. Ibid.

12. The only sense the word can have, when used as a noun, is "snake" or (once or twice) "maggot" (which is not the sense in Juvenal).

13. The detail is also found in Plut. Mor. 380F4-6 and [Arist.] Mir. ausc. 2. 832a15. Cf. also Isid. Orig. 12.7 ciconiae. . . serpentium hostes (i.e., Vergil's invisa colubris). 
Apollonius Rhodius Argonautica 2. 500-527 or Callimachus Aetia 3, fragment 75 Pfeiffer (which itself suppresses the name, referring to him as ó Keĩo /

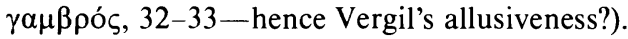

(b) 2. 122-24 "aut quos Oceano propior gerit India lucos, / extremi sinus orbis, ubi aëra vincere summum / arboris haud ullae iactu potuere sagittae." $\mathrm{He}$ does not name the banyan tree; the reader must recover the identity of that tree from Theophrastus Historia plantarum 4. 4. 2-4, where the tree is named. ${ }^{14}$

(c) 3. 1-2 "et te memorande canemus / pastor ab Amphryso." The subject is Apollo, but the general reader will have difficulty making the identification unless he is aware of Vergil's source, Callimachus Hymn to Apollo 47-49:

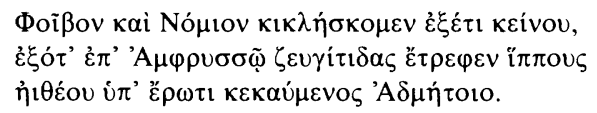

This is the only instance before Vergil where the Amphryssus (which is in any case not found before the Alexandrians) is connected with Apollo's service to Admetus. Vergil glosses Callimachus' Nó $\mu$ to $\varsigma$ with pastor, and the position of $a b$ Amphryso mirrors that of '̇ं ' 'A $\mu \varphi \rho v \sigma \sigma \tilde{\varphi}$.

(d) 3. 425-34 "est etiam ille malus Calabris in saltibus anguis...."Vergil feels no need to name the chersydrus, for he expects us to recover it by recognizing his close adaptation of Nicander Theriaca 359-71, where, again, the snake is named. At the same time he allusively aids the identification by glossing the two components of the snake's name with a heavy concentration of words connoting "wet" (i.e., v̋ $\delta \omega \rho)$, in 428-30 (amnes, fontibus, madent, udo, pluviali-

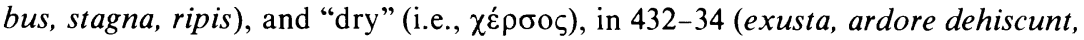
siccum, siti, aestu).

The manner of these references, then, suggests a specifying literary antecedent for the general identification candida ... avis longis invisa colubris. Although no certain antecedent survives, the information concerning storks, snakes, and the Thessalians noted above cannot have originated with Pliny. We cannot be sure, but an obscure fragment from Callimachus (to whom such details would have appealed), attributed to the Hecale (the model of epyllia for the Roman poets),

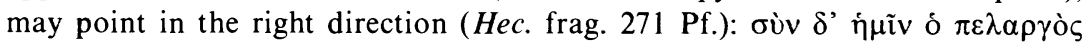

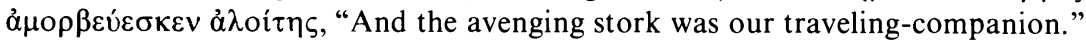
Pfeiffer (ad loc. and in his addenda et corrigenda) suggested that the line may belong in the mouth of another bird. If so, $\dot{\alpha} \lambda$ oí $\tau\rceil \varsigma$ could have special significance: the bird that traditionally kills snakes (perennial enemies to birds) would, from a bird's-eye view, qualify for the title "Avenger." It would be in Vergil's manner to represent this with the words longis invisa colubris.

RICHARD F. THOMAS Harvard University

14. For the remarkably close dependence of G. 2. 1-135 on the Hist. pl., cf. P. Jahn, "Eine Prosaquelle Vergils und ihre Umsetzung in Poesie durch den Dichter," Hermes 38 (1903): 244 64; W. Mitsdörffer, "Vergils Georgica und Theophrast," Philologus 93 (1938): 449-75. 